\title{
Genetic Diversity and Agro-morphological Characteristics of 50 Upland Rice Genotypes Derived from Recurrent Selection
}

\author{
Sahri Yono, Reny Herawati*, Hesti Pujiwati \\ Department of Crop Production, Faculty of Agriculture, University of Bengkulu \\ WR Supratman St, Kandang Limun, Bengkulu 38371, Indonesia
}

\author{
ARTICLE INFO \\ Keywords: \\ genetic diversity \\ agro-morphological characters \\ genotype \\ recurrent selection \\ Article history: \\ Received: August 24, 2018 \\ Accepted: Nov 25, 2018 \\ *Corresponding author: \\ E-mail: reny.herawati@unib.ac.id
}

\begin{abstract}
Rice (Oryza sativa L.) is the most important crops commodity in Indonesia because it is the main staple for the people of Indonesia but currently, in Indonesia, the production of rice is still not maximal so it cannot meet the demand of Indonesian people for national food needs. Therefore, it is necessary for rice plants that have high production and tolerant to various stresses. Plant breeding is one of the ways that can be done to increase the production of rice, one of which is the method of cross-recurring selection. Genetic diversity is a variation of characteristics that are inherited in the same species population. This study aims to obtain information about genetic diversity and agromorphological characters of 50 genotypes rice derived from the recurrent selection. This research was conducted from August until December 2017 in Rawa Makmur Village, Bengkulu Province with the height of place from sea level $\pm 2 \mathrm{~m}$. The study used a Completely Randomized Block Design (RAK) with 3 replications. The seeds used were 50 genotypes of rice from previous cross-selection results from Bugis/N-22 crossbreeds, Bugis/IR-7858-1, Sriwijaya/N-148, Sriwijaya/IR-7858-1. The results showed that the genetic diversity of rice is quite narrow to moderate, but there are some rice characters that have medium to high heritability value that was plant height, harvesting age, flowering age, the total number of tillers and panicle length, so that character can be used for the next generation rice selection. The genotypes produced by Bugis/IR-7858-1 crosses have panicle length, filled grain per panicle, and high grain weight/hill resulting in high yield potential..
\end{abstract}

\section{INTRODUCTION}

Rice (Oryza sativa L.) is the most important crop commodity in Indonesia because it is the main staple for Indonesian people. Most Indonesians consume rice as a source of carbohydrate. Indonesian rice productivity in 2013 was 71.29 million tons of dry weight grain (DWG) with a harvested area of 13,445,524 ha. Indonesia's population increases with a growth rate of $1.36 \%$ per year while rice consumption in 2013 reaches $130 \mathrm{~kg}$ per capita, meaning that the national rice demand in 2035 will reach 43 million tons, equivalent to 76 million tons of dry weight grain (DWG) (Tatuh et al., 2013). Rice production in 2015 was 75.36 million tons of DWG or increased by 4.51 million tons (6.37 percent) compared to 2014. While for rice production in Bengkulu in 2014 as many as 593194 tons decreased in 2015 to 578 654 tons or decreased by $2.45 \%$ (BPS, 2015) .
The area of rice plantations in Indonesia is estimated at 11-12 million ha, spread over various land typologies such as lowland rice (5.10 million ha), rainfed lowland (2.10 million ha), fields (1.20 million ha), and tidal land. More than $90 \%$ of national rice production is produced from lowland rice, and more than $80 \%$ of the total lowland rice have been planted with superior varieties. This information shows that superior varieties, especially rice, are the key to the success of increasing rice production in Indonesia (Susanto et al., 2003).

Therefore, to face the challenges of food needs, especially rice, plant breeding experts are interested in developing superior varieties because of the availability of rainfed lowland areas that are more potential than irrigated rice fields. For this reason, a comprehensive understanding of the characteristics of the abiotic environment such as climate and land conditions are needed, biotics such as pests, diseases

ISSN: 1410-3354 / e-ISSN:2615-7136

Cited this as: Yono,S., R.Herawati, and H. Pujiwati. 2018. Genetic diversity and agro-morphological characteristics of 50 upland rice genotypes derived from recurrent selection. Akta Agrosia 21(1):33-40. 
and weeds and their interaction with plants. Furthermore, identified types of drought, understanding of the mechanism of plant adaptation, understanding of genes that bequeath the properties of endurance and aspects of environmental management, so that there is a meeting point between the available varieties with the physical characteristics of the environment to suppress yield loss (Ishitani, 2004).

According to Sitaresmi et al., (2017) local varieties grown from generation to generation have the possibility that these local varieties are tolerant of biotic and abiotic stresses but with specific regions. The use of parents from local varieties can be developed for superior specific genotypes so that the varieties obtained have extensive genetic variability.

Recurrent selection is a method of selecting and crossing selected plants from a population systematically to form a better new population. In other words, this method is a procedure for gathering the traits that are expected from a combination of crosses by crossing between selected segments continuously so that a population that is better than the previous population, because it consists of plants that have a combination of traits (Fehr, 1987).

Genetic diversity is a variation of characteristics that are inherited in the population of the same species. Genetic differentiation in species occurs as a result of sexual reproduction, genetic differences between individuals combined in their offspring to produce new combinations of genes or from mutations that cause DNA changes (Mulyaningsih and Indrayani, 2014). The cross between two individuals of a similar type of life is one of the causes. The combination of the composition of gene devices from these two parents will cause individual diversity in one species in the form of varieties that occur naturally or artificially. A diversity that occurs naturally is the result of adaptation or adjustment of each individual to the environment. Environmental factors also influence the visible nature (phenotype) of an individual in addition to being determined by genetic factors (genotype). While artificial diversity can occur, among others, through cross-breeding (hybridization) (Mulyaningsih and Indrayani, 2014).

The diversity of rice is reflected through agromorphology based on qualitative and quantitative characters. Diversity is shown through the diversity coefficient $(\mathrm{CV})$, the large diversity reflected by $\mathrm{CV}>$ $20 \%$ (Suhartini, 2010). Identification of diversity by means of characterization will produce data containing information about the properties of morphological characters (color of flowers, leaf shape, etc.) and agronomic (age of harvest, plant height, production, etc.) (Suhartini, 2010). Morphological characterization is more important than molecular characterization because it is easy to do and appear clearly. The morphological markers used are markers based on Mendel's simple heredity, such as shape, color, size, and weight. Phenotypic diversity in a plant population is very important and can be used as an estimator of genetic diversity, so that selection with the aim of getting superior characters can be done (Kristamtini et al., 2015).
Heritability can be used as a basis in determining the selection program. Selection in the early generation is carried out if the value of heritability is high, on the contrary, if it is low then the selection of the next generation will succeed because of the opportunity for increased diversity in the population (Falconer, 1970). From the results of previous studies, 180 rice lines were obtained from recurrent selection, after a drought screening in the greenhouse was obtained 50 genotypes that were ready to be tested further. This study aims to obtain information about genetic diversity and agro-morphological characters of 50 rice genotypes resulting from recurrent selection.

\section{MATERIALS AND METHODS}

The research was conducted in August December 2017 at Rawa Makmur Village, Bengkulu Province, Indonesia on an altitude of \pm 2 meters above sea level. The experiment using Randomized Complete Block Design (RCBD) and 3 replications. Each genotype is planted in one row consisting of 20 populations so that \pm 3000 plants are obtained. The materials used were 50 rice genotypes resulting from a recurrent selection from Bugis x N-148 crosses, Bugis x IR-7858-1, Sriwijaya x N-148, and Sriwijaya $x$ IR-7858-1 (Herawati et al., 2017b ) and NPK fertilizer. The materials used in this research are nails, hammers, bamboo, waring, meters, ropes, nets, hoes, scales, laptops, plastic envelopes/bags.

Seeding is carried out on trays or buckets of each genotype of seedling containers so that the seeds that are sown are easily cared for and not mixed with other seeds. Planting is done after the seedling age is 14 days and each genotype treatment is planted one row of plants with a plant population of 25 plants per line.

Replanting is done on plants that die at the age of a week after planting. Fertilization is carried out regularly twice, which is done when the rice is \pm 10 days old and 30 days after planting. Fertilization is done by spreading or sowing NPK fertilizer between rows of rice plants. Weeding done manually, by removing weeds and dumping them to other places so they don't grow again. Pest and disease control pest control snails and stink bug are carried out chemically by spraying molluscicides with active ingredients of niclosamide $250 \mathrm{~g} / 1$ and pesticides with active ingredients deltamethrin $100 \mathrm{gr} / \mathrm{l}$. The installation of nets is done when the rice starts to panicle excert or flowering until the rice is ready for harvest, the installation of nets aims to protect the rice from bird attacks. Harvesting is done after rice grain has been $85 \%$ yellowed in each panicle. Observations include plant height, flowering age, harvesting age, the total number of tillers, the number of productive tillers, the number of non-productive tillers, panicle length, the number of filled grain/panicle, the number of empty grains, grain weight per hill, and 1000 grain weight.

Data analysis consisted of various phenotypes $\left(\sigma^{2} p\right)$, environmental variance $\left(\sigma^{2} \mathrm{e}\right)$ and genetic variance $\left(\sigma^{2} g\right)$ calculated based on the expected value of the middle square of each parameter. The 
coefficient of genetic diversity (GDC) and the coefficient of variability in penotypes (PDC) were calculated based on the Singh \& Chaudhary (1979).

Genotype Diversity Coefficient (GDC) \& Phenotype Diversity Coefficient (PDC) is used to estimate the extent or absence of genetic diversity of each character calculated based on the following formula (Knight 1979):

$$
\mathrm{GDC}=\frac{\sqrt{\boldsymbol{\sigma 2 \mathrm { g }}}}{\overline{\boldsymbol{x}}} \times 100 \% \quad \mathrm{PDC}=\frac{\sqrt{\sigma 2 \mathrm{p}}}{\bar{x}} \times 100 \%
$$

Where, $n \sigma 2 g=$ genetic variation, $\sigma 2 p=$ variety of phenotypes, = average population, Criteria: narrow $(0-10 \%)$, moderate $(10-20 \%)$, and wide $(>20 \%)$

Heritability in the broadest sense (hbs) is calculated based on the formula:

$$
\mathrm{hbs}=\frac{\sigma^{2} \mathrm{~g}}{\sigma^{2} \mathrm{~g}+\sigma^{2} \mathrm{e}}
$$

The hbs values are grouped according to Standfield (1983): $<20 \%=10 \mathrm{w}, 20-50 \%=$ moderate, and $>50 \%=$ high .

\section{RESULT AND DISCUSSION}

\section{Agronomic Characters of Rice}

The results of analysis of variance and variety of rice on all variables observed showed significant differences such as flowering age, the total tillers number, the number of productive tillers, the number of non-productive tillers, the number of filled grains per panicle, grain weight per hill and 1000 grain weight whereas for the variables of harvest age, plant height, panicle length, and the number of empty grains per panicle showed very significant differences (Table 1).

The genetic diversity coefficient (GDC) of all observed variables is categorized as narrow to moderate if carried out according to Knight's criteria (1979). The character of flowering age, harvest age, plant height, panicle length, the number of filled grains per panicle and weight of 1000 grains included in narrow criteria while for the character of total tillers, the number of productive tillers, the number of non-productive tillers, the number of empty grains per panicle and grain weight per hill were classified as medium criteria, with the highest GDC results found in the variable number of empty grains per panicle, ie $19.30 \%$ and the lowest in the harvest age variable with $1.32 \%$ (Table 1). Based on these groupings, the genetic diversity of rice is classified in narrow genetic diversity, this is in accordance with the opinion of Murdaningsih et al., (1990) which states that the characters with relatively low and rather low GFCs are classified as narrow genetic diversity and characters with relatively high GFC criteria. and high is classified as a broad genetic diversity character

The character of plants with low GDC indicated that the selection was less effective because the experiments did not show an increase in the genetic potential of the observed characters. This is the same as the opinion of Zen and Bahar, (2001) which states that effective character selection will be able to increase the genetic potential of characters in the next generation selection. According to Hartati et al. (2012) narrow genetic diversity is caused by greater environmental influences compared to genetic factors for these characters.

The heritability estimation values of all characters observed ranged from 0.01 to the number of nonproductive tillers and up to 0.56 for the character height of plants (Table 1). Based on the criteria according to Stanfield (1983), characters with high heritability are plant height, while for characters with moderate heritability, namely flowering age, harvest age, panicle length and also the number of empty grains per panicle, and for the characters included in

\begin{tabular}{|c|c|c|c|c|c|c|c|c|}
\hline Characters & MS & $\mathrm{Fc}$ & $\sigma_{g}^{2}$ & $\sigma_{p}^{2}$ & $\mathrm{GDC}(\%)$ & criteria & $h^{2}$ bs & criteria \\
\hline Flowering & 22,16 & $2,26^{*}$ & 4,12 & 13,90 & 2,89 & narrow & 0,29 & medium \\
\hline Harvesting & 6,55 & $3,18 * *$ & 1,49 & 3,55 & 1,32 & narrow & 0,42 & medium \\
\hline Plant height & 492,32 & $4.91 * *$ & 130,67 & 230,97 & 8,35 & narrow & 0,56 & high \\
\hline The total number of tillers & 20,45 & $1,57^{*}$ & 3,72 & 16,72 & 15,52 & medium & 0,22 & medium \\
\hline $\begin{array}{l}\text { The number of productive } \\
\text { tillers }\end{array}$ & 19,55 & $1,57^{*}$ & 2,35 & 14,84 & 13,80 & medium & 0,15 & Low \\
\hline $\begin{array}{l}\text { The number of non productive } \\
\text { tillers }\end{array}$ & 1,09 & $1,05^{*}$ & 0,01 & 1,05 & 10,46 & medium & 0,01 & low \\
\hline Panicle length & 4,51 & $3,18^{* *}$ & 1,03 & 2,45 & 3,37 & narrow & 0,42 & Medium \\
\hline $\begin{array}{l}\text { The number of fill grain per } \\
\text { panicle }\end{array}$ & 1265,47 & $1,46 *$ & 133,48 & 998,51 & 7,90 & narrow & 0,13 & Low \\
\hline $\begin{array}{l}\text { The number of un-fill grain per } \\
\text { panicle }\end{array}$ & 1288,22 & $2,45^{* *}$ & 254,23 & 779,75 & 19,30 & medium & 0,32 & Medium \\
\hline Grain weight per hill & 95,99 & $1,35^{*}$ & 5,54 & 84,90 & 11,20 & medium & 0,06 & Low \\
\hline 1000 grains weight & 17,15 & $1,15^{*}$ & 0,75 & 15,64 & 2,91 & narrow & 0,04 & low \\
\hline
\end{tabular}

Table 1 . The analysis of variance and Genetic diversity of rice

${ }^{*}=$ significant difference, ${ }^{* *}=$ very significant difference, $M S=$ mean square, $F c=F$ count,$\sigma_{g}^{2}=$ genotype variability, $\sigma_{p}^{2}=$ phenotype variability, $G D C=$ genotype diversity coeficient, $P D C=$ phenotype diversity coeficient, hbs $=$ broad sense heritability 
the criteria of low heritability namely the number of productive tillers, the number of non-productive tillers, the number of filled grain per panicle, grain weight per hill and also 1000 weight grains. According to Wicaksana (2001), characters who have high heritability values indicate that genetic factors are more dominant or genetic factors contribute more than environmental factors and selection of these characters can be started in the early generation. If a population has a high heritability value for a character, then mass selection will be more efficient to improve the character.

Although all the characters observed had a narrow genetic diversity, the character of plant height, harvest age, the age of flowering, the total number of tillers, and panicle length had medium to high heritability estimates, thus selection for genetic improvement could be done on the characters (Table 1).

\section{Agro-morphological Characters}

The diversity of agro-morphological characters of rice populations greatly determines the success of plant breeders in obtaining a new genotype with the desired combination of superior characters. The greater the diversity of available populations, the greater the chance of getting a genotype with the desired character. The appearance of agromorphological characters of observed rice plants is presented in Table 2 to Table 7.

Plant height in all genotypes varies greatly, the highest plant height is found in Bugis / N-148 crosses, $166.5 \mathrm{~cm}$, but the highest average is from Bugis/IR7858 -1 crossing, which is $151.58 \mathrm{~cm}$ and the lowest range comes from of the Sriwijaya/N-148 crossing population of $105 \mathrm{~cm}$ with an average of $127.83 \mathrm{~cm}$ (Table 2). Plant height observed to have genetic progress, when viewed in the study Herawati et al. (2017b) had an average plant height of 139.5 for elders from Bugis/IR-7858-1 and 109.7 for elders of Sriwijaya/IR-7858 -1. According to IRRI (2013), the height of lowland rice is divided into 3 categories, namely low: if the plant height is below $110 \mathrm{~cm}$, medium: if plant height ranges from $110 \mathrm{~cm}-130$ $\mathrm{cm}$, and high: if the height of rice plants is more than $130 \mathrm{~cm}$. The height of the plant from the Bugis/ IR7858-1 and Bugis/N-148 crosses is in the high category, while for the average plant height of the crossing from Sriwijaya/N-148, and Sriwijaya/IR7858-1 are in the category medium.

The productive tillers are tillers that produce panicles and form after plants enter the generative phase. Not all tillers will produce productive tillers. The results showed that the average productive tillers for Bugis/IR 7858-1 genotypes are 11.16, Bugis/N148 which is 10.50 , Sriwijaya/N-148 which is 14.08 , while for Sriwijaya/IR-7858-1 that is 12,72. The highest average number of tillers derived from Sriwijaya/N-148 crosses, which is 14.08 and the lowest number of tillers is from Bugis/N-148 crosses, 10.50 (Table 2). Variable productive tillers also showed better growth compared to previous studies conducted by Herawati et al. (2017b) in the F3 generation which produces the highest productive is 9.3 tillers.

Flowering age is an important factor in a plant growth process. Flowering age also shows that the plant has entered the generative phase. Flowering age factors can affect the age of crop harvest. Based on the results of the analysis of diversity there are significant differences in the variable age of flowering between all existing lines. The flowering age of each genotype varies between 61-79 HST with the fastest average value coming from Bugis/ N-148 crosses which are 68.08 DAP and the slowest average comes from Sriwijaya/N-148 crosses which are 71, 44 DAP (Table 3). Flowering age was observed more quickly when compared with the results of previous studies on F3 generation in Bugis/IR-7858-1 range 83 -110 days and Sriwijaya/IR-7858-1 ranged from 8595 DAP (Herawati et al., 2017a) which means that

Table 2. Range and average of plants height and the number of productive tillers

\begin{tabular}{|c|c|c|c|c|c|}
\hline \multirow[t]{2}{*}{ Crossing } & \multirow{2}{*}{$\begin{array}{l}\text { Line } \\
\text { number }\end{array}$} & \multicolumn{2}{|c|}{ Plant height $(\mathrm{cm})$} & \multicolumn{2}{|c|}{ Productive tiller } \\
\hline & & Range & Mean & Range & Mean \\
\hline Bugis / IR-7858-1 & 14 & $123-166$ & 151.58 & $5-20.34$ & 11.16 \\
\hline Bugis / N-148 & 4 & $120.5-166.5$ & 149.68 & $5.5-15.67$ & 10.50 \\
\hline Sriwijaya / N-148 & 12 & $105-153$ & 127.83 & $8-28.67$ & 14.08 \\
\hline Sriwijaya / IR-7858-1 & 20 & $109.5-156.67$ & 129.29 & $7-22.67$ & 12.72 \\
\hline
\end{tabular}

Table 3. Range and average of flowering and harvesting

\begin{tabular}{lcccccc}
\hline Crossing & \multirow{2}{*}{$\begin{array}{l}\text { Line } \\
\text { number }\end{array}$} & \multicolumn{2}{c}{ Flowering (DAP) } & & \multicolumn{2}{c}{ Harvesting (DAP) } \\
\cline { 3 - 4 } & & Range & Mean & & Range & Mean \\
\hline Bugis / IR-7858-1 & 14 & $63-76$ & 70.64 & & $89-97$ & 92.07 \\
Bugis / N-148 & 4 & $61-75$ & 68.08 & & $90-95$ & 92.25 \\
Sriwijaya / N-148 & 12 & $64-75$ & 71.44 & & $89-95$ & 92.61 \\
Sriwijaya / IR-7858-1 & 20 & $62-79$ & 69.6 & & $89-96$ & 92.9 \\
\hline
\end{tabular}


the selection of flowering age characters has been carried out effectively.

Harvest age is the final phase of the plant in completing its life cycle. The harvesting age of rice is also influenced by genetic and organic matter content in the soil to meet crop needs. Besides that, the harvest age is also affected by the age of flowering and the maturation process of the rice grains. The faster flowering and the process of grains filling, the faster the harvest age will be (Azalika, 2016). The harvesting age of rice plants observed ranged from 89 -97 DAP, with the average age of the longest harvest coming from the Sriwijaya/IR-7858-1 crossing of 92.9 DAP while the fastest harvesting age came from Bugis/IR-7858-1 crosses, namely 92,07 DAP (Table 4 ), also shows the acceleration of grain maturation is around 23 days compared to previous studies (Herawati et al., 2017a). This is consistent with the results reported by BBPTP (2016) flowering age and harvesting age for new types of rice (Inpari 42 and Inpari 43) ranging between 80-85 and 111-112 days after planting. According to BBPTP (2016), the classification of the age of rice is long if $>151$ days after planting (HSS), medium 125-150 HSS, early 105-124 HSS, very early 90-104 HSS, ultra early $<90$ HSS. If the results of the rice experiments were carried out in the classification of rice age according to BBPTP, the rice plants observed were included in the early maturity category, ie the average harvest age ranged from 92.07 to 107.9 days after planting.

The tillers are a product of the vegetative phase of the rice where the number of tillers determines the yield because the more the number of tillers, the more the number of panicles that produce grain. Genetically varieties determine the number of tillers (Yoshida, 1981). Based on Table 4, it can be seen that the total tillers range of all genotypes observed were 5-28.67, the highest tillers were 14.08 and the lowest was 10.50 tillers. Non-productive tillers of rice observed ranged from 0-6 with the highest average of 1.37 and the lowest 1.07 (Table 4). According to BBPTP (2017), the number of tillers in the desired new type of rice ranges from 12-18, but all of the tillers are productive.

Panicle length is one of the important factors in the rice yield component because the longer panicle, the more grain will be produced. This is the same as the research by Zulman and Widodo (2009) and Mahmud and Purnomo (2014) which revealed that with a longer panicle length, there could be a lot of grain formation. This will provide an opportunity for the formation of filled grains per panicle that can affect grain weight per hill.

The results of the analysis on panicle length variables showed significant differences, this is presumably because the plants observed came from different parents so that the plant's genetic factors still affect the panicle length. The highest length of panicle derived from Sriwijaya/N-148 elders, namely $25 \mathrm{~cm}-34.34 \mathrm{~cm}$. The panicle length observed was better compared to the results of the study Herawati et al. (2017b) which produces panicles in the F3 generation from Bugis/IR-7858-1 and Sriwijaya/IR$7858-1$ elders on average $22.4 \mathrm{~cm}$ and $21.9 \mathrm{~cm}$.

Fill grain per panicle is the total amount of filled grain in the main panicle observed. According to Gardner (1991) grain filling requires photosynthate results from leaves and photosynthetic flow from other parts. If plants experience obstacles in the photosynthesis process due to environmental factors, it can cause photosynthate supply to the seeds to be reduced resulting in empty grains. The results of observations on the number of filled grains per panicle were high compared to the new type of rice conducted by Abdullah (2002) which showed that the average yield of filled grains from IRRI parents was 159 grains.

The characteristics of panicle length and number of filled grains per panicle of the same parent, namely Bugis x IR-7858-1 showed good growth, which initially only panicles ranged from 19.9 to $27.2 \mathrm{~cm}$ can reach growths of $28-34 \mathrm{~cm}$, Likewise, the number

Table 4. Range and average of the total number of tiller and the total number of a non-productive tiller

\begin{tabular}{lcccccc}
\hline \multirow{2}{*}{ Crossing } & Line & \multicolumn{2}{c}{ total number of tiller } & & \multicolumn{2}{c}{$\begin{array}{c}\text { total number of non pro- } \\
\text { ductive tiller }\end{array}$} \\
\cline { 3 - 4 } & number & Range & Average & & Range & Average \\
\hline Bugis / IR-7858-1 & 14 & $5-20.34$ & 11.16 & & $0-3$ & 1.07 \\
Bugis / N-148 & 4 & $5.5-15.67$ & 10.50 & & $0-3$ & 1.23 \\
Sriwijaya / N-148 & 12 & $8-28.67$ & 14.08 & & $0-5$ & 1.37 \\
Sriwijaya / IR-7858-1 & 20 & $7-22.67$ & 12.72 & & $0-6$ & 1.35 \\
\hline
\end{tabular}

Table 5. Range and average of panicle length and fill grains per panicle

\begin{tabular}{|c|c|c|c|c|c|}
\hline \multirow[t]{2}{*}{ Crossing } & \multirow{2}{*}{$\begin{array}{l}\text { Line } \\
\text { number }\end{array}$} & \multicolumn{2}{|c|}{ Panicle length $(\mathrm{cm})$} & \multicolumn{2}{|c|}{ Fill grain/panicle } \\
\hline & & Range & Mean & Range & Mean \\
\hline Bugis / IR-7858-1 & 14 & $28.0-34.0$ & 30.42 & $56-223$ & 158.48 \\
\hline Bugis / N-148 & 4 & $28.0-32.5$ & 30.12 & $112-188.67$ & 156.63 \\
\hline Sriwijaya / N-148 & 12 & $25.0-34.3$ & 30.12 & $71-207$ & 139.17 \\
\hline Sriwijaya / IR-7858-1 & 20 & $26.5-32.7$ & 29.90 & $76.5-210.5$ & 139.76 \\
\hline
\end{tabular}


of filled grains per panicle showed an increase in the average yield of grain filled up to 90 grains from previous studies (Herawati et al., 2017a). According to BBPTP (2017), rice that suitable the conditions of Indonesia with a tropical climate, the presence of pests and diseases is a major problem. Suitable NPTs (New Plant Type) are those that have moderate but all productive tillers (12-18 stems), grain numbers per panicle 150-250 grains, percentage of filled grains 85 $-95 \%$, weight of 1,000 grains $25-26 \mathrm{~g}$, sturdy and short stems $(80-90 \mathrm{~cm})$, early maturity $(110-120$ days), flag leaves upright, narrow, shaped $\mathrm{V}$, green to dark green, 2-3 last leaves do not senescence quickly, roots are numerous and spread deep, resistant to pests and main disease, slim grain, and good quality of rice. With these properties, NPTs varieties are expected to produce 9-13 tons of DGW.

Empty grain is grain that develops not perfect, it can be caused by environmental and genetic factors of the plant. Environmental factors that can affect empty grain are attacks of pests and plant diseases such as pest attacks when the young panicle emerges so that it can not grow perfectly or empty (Willis, 2001). In addition, according to Zulman and Widodo, (2009) empty grain can also occur due to lack of distribution of assimilating to seeds.

The grain weight per hill observed was different, this was because the plants tested came from different elders so the genetic factors of the parents would affect the yield of the grain weight per hill, but it would also work well if the nutrient requirements needed by these plants are fulfilled, especially potassium nutrients, this is similar to Zarah (2001) who said potassium nutrients play a role in starch formation, where catalase starch is the only enzyme that functions to combine sugar into a long series called starch. Changes in dissolved sugar to starch are the main stages of the rice filling period. Therefore if the need for potassium does not meet the needs of plants, the weight of the grain will decrease.
The number of empty grains per panicle showed a decrease from the previous study only had an average of 18.9 - 91.24 grains, this was probably due to the attack of pests when the experiment was conducted so that a lot of grain was empty. The same thing was reported by Oktaviani et al. (2017), which says the level of the emptiness of grain is due to genetic influences and environmental factors. However, this is not followed by the character of grain weight per hill which shows an average increase from before only $19.4 \mathrm{~g}$ to $21.15 \mathrm{~g}$, but in observation, there was grain weight per hill which reached $55.07 \mathrm{~g}$.

The results of the analysis of the 1000 weight variable have a significant effect, it is because the size of the rice grain observed is different. The character that determines the increase in production in rice is the number of panicles per hill, the number of filled grains per panicle, and the grain weight per hill (Xing and Zhang, 2010). The weight of 1000 grains was determined by its genetic, but environmental factors also affected, especially the factors of seed formation. The results of the range and mean weight of 1000 grains, the highest yield was found in plants originating from the Bugis crossing/N-148 which was in the range of $26.5-38$ grams and an average of 30.98 grams (Table. 7).

\section{CONCLUSION}

All variables observed were narrow to medium genetic diversity. The character of plant height, flowering age, harvest age, the total number of tiller and panicle length have medium to high heritability values so that the character can be selected to improve rice yield. The genotypes produced by Bugis/IR-7858-1 crosses have panicle length, filled grain per panicle, and high grain weight/hill resulting in high yield potential. The results of this study are expected to be references for the selection of rice

Table 6. The range and average of the number of empty grains and grain weight per hill

\begin{tabular}{lccccc}
\hline \multirow{2}{*}{\multicolumn{1}{c}{ Crossing }} & \multirow{2}{*}{$\begin{array}{c}\text { Line } \\
\text { number }\end{array}$} & \multicolumn{2}{c}{$\begin{array}{c}\text { The number of Empty } \\
\text { grains/panicle (gram) }\end{array}$} & \multicolumn{2}{c}{ Grain weight/hill (gram) } \\
\cline { 3 - 6 } & & Range & mean & Range & mean \\
\hline Bugis / IR-7858-1 & 14 & $31-165$ & 91.24 & $4.9-55.07$ & 21.15 \\
Bugis / N-148 & 4 & $27.5-124.67$ & 90.81 & $10.2-27.67$ & 20.06 \\
Sriwijaya / N-148 & 12 & $38-141$ & 81.54 & $7.1-51.96$ & 22.26 \\
Sriwijaya / IR-7858-1 & 20 & $20-141$ & 75.51 & $7.4-52.4$ & 20.35 \\
\hline
\end{tabular}

Table 7. Range and average of 1000 weight grain

\begin{tabular}{lccc}
\hline \multirow{2}{*}{ Crossing } & \multirow{2}{*}{ Line number } & \multicolumn{2}{c}{1000 grains weight (gram) } \\
\cline { 3 - 4 } & & Range & mean \\
\hline Bugis / IR-7858-1 & 14 & $23.0-37.0$ & 29.97 \\
Bugis / N-148 & 4 & $26.5-38.0$ & 30.98 \\
Sriwijaya / N-148 & 12 & $19.5-36.3$ & 29.31 \\
Sriwijaya / IR-7858-1 & 20 & $14.0-38.5$ & 29.76 \\
\hline
\end{tabular}


characters in the next generation.

\section{ACKNOWLEDGMENTS}

Acknowledgments and awards to my lecturer Dr.Reny Herawati who has facilitated this research through National Strategic Research funds.

\section{REFERENCES}

Abbdullah, B. 2002. Perakitan Dan Pengembangan Varietas Padi Tipe Baru. Balai besar penelitian tanaman padi. Itb.3 h.72.

Azalika,R.P., 2016. Pertumbuhan Dan Hasil Padi Sirantau Pada Pemberian Beberapa Jenis Dan Dosis Pupuk Kandang. pertanian. universitas Bengkulu. Bengkulu.

Badan Pusat Statistik (BPS). 2015. Produksi padi tahun 2014 -2015. http://www.bps.go.id diakses tanggal 29 november 2016.

Balai Besar Penelitian Tanaman Padi (BBPTP). 2016. Klasifikasi tanaman padi.. http:// bbpadi.litbang.pertanian.go.id. (diakses tanggal 4 maret 2018)

Balai Besar Penelitian Tanaman Padi (BBPTP). 2017. Perkembangan dan prospek perakitan padi tipe baru di Indonesia. http:// bbpadi.litbang.pertanian.go.id. (diakses tanggal 4 maret 2018)

Falconer, D.S. 1970. Introduction to quantitative genetic, The Ronald Press Company. New York. 365 p.

Fehr, W.R. 1987. Principles of cultivar development, vol. 1. Theory and technique. McGraw-Hill, Inc. New York St. Louis, USA. p.535.

Gardner, 1991. Fisiologi Tanaman Budidaya. UI Press: Jakarta

Hartati, Rr.S, A. Setiawan, B.Heliyanto , dan Sudarsono .2012. Keragaman Genetik, Heritabilitas, Dan Korelasi Antar Karakter 10 Genotipe Terpilih Jarak Pagar (Jatropha Curcas L.) Jurnal Littri 18(2): $74-80$

Herawati, R. I. Entang. Rustikawati. Mukhtasar. 2017a. Genetics Diversity and Agronomic Characters of F3 Lines Selected by Recurrent Selection for Drought Tolerance and Blast Resistance of Bengkulu Local Rice Varieties. International Journal and Advance Science Engineering Information Technology. 7(3): 922-926

Herawati, R. Masdar, D.W Ganefianty, B. Hermawan dan Alnopri. 2017b. Screening and Identification of Upland Rice Lines Derived Recurrent Selection for Drought Tolerance. International Journal and Advance Science Engineering Information Technology. 7(6): 23222326

International Rice Research Institute. 2013. Standart Evaluation System For Rice. Manila, Philippines. 5:13
Ishitani, M. 2004. Applying Genomics Tools to Understand Drought Tolerance Mechanisms. Agrobiodiversity and Biotechnology Project. International Center for Tropical Agriculture. Paper.

Knight, R. 1979. Quantitative genetics, statistics and plant breeding. In G.M. Halloran, R. Knight, K.S. Mc Whirter and D.H.B.Sparrow (ed.) Plant breeding. AustraliaVice Consellors Comite. Brisbane. p. 41-78.

Kristamtini, S.Widyayanti, Sutarno, dan Sudarmaji. 2005. Keragaman Genetik Lima Kultvar Lokal Padi Beras Hitam Asal Yogyakarta Berdasarkan Sifat Morfologi. Prosiding Seminar Nasional Sumber Daya 90 Genetik Pertanian. Balai Pengkajian Teknologi Pertanian (BPTP) Yogyakarta.

Mahmud, Y. Dan S.S. Purnomo. 2014. Keragaman Agronomis Beberapa Varietas Unggul Baru Tanaman Padi (Oryza Sativa L.) Pada Model Pengelolaan Tanaman Terpadu. Jurnal IImiah Solusi. 1(1):1-10

Mulyaningsih, E.S., \& Indrayani S. 2014. Keragaman Morfologi dan Genetik Padi Gogo Lokal Asal Banten. Pusat Penelitian Bioteknologi LIPI. Jurnal Biologi Indonesia 10 (1): $119-128$

Murdaningsih, H. K., A. Baihaki, G. Satari, T. Danakusuma, A.H. Permadi. 1990. Variasi genetik sifat-sifat tanaman bawang di Indonesia. Zuriat 1(1):32-36.

Oktaviani, N.I. I.G P. M. Aryana dan U.M. Yakop. 2017. Penampilan Fenotipe Dan Heritabilitas Padi Beras Merah (Oryza Sativa L.) Hasil Seleksi Silang Tunggal Serta Seleksi Silang Berulang. Crop agro. 10(2):1-7

Singh, R.K., R.D. Chaudhary. 1979. Biometrical Methods in Quantitative Genetic Analysis. Kalyani Publishers. New Delhi.

Sitaresmi T, R.H. Wening, A.T. Rakhmi, N. Yunani, dan U. Susanto. 2013. Pemanfaatan plasma nutfah padi varietas lokal dalam perakitan varietas unggul. Iptek tanaman pangan. 8(1).

Standfield, W.D. 1983. Theory and problems of genetics, $2^{\text {nd }}$ edition. Schain.s outline series. Mc.Graw Hill book Co. delhi.

Suhartini. T. 2010. Keragaman Karakter Morfologis Plasma Nutfah Spesies Padi Liar (Oryza spp.) Bulletin Plasma Nutfah 1:17-28.

Susanto, U, A.A. Darajad, dan B. Suprihatno. 2003. Perkembangan Pemuliaan Padi Sawah Di Indonesia. Jurnal litbang pertanian. Balai penelitian padi sukamandi. 22(3).

Tatuh, J. Peter.R.H. dan Johannes E. X. R. 2013. Analisis Dampak Perubahan Iklim Terhadap Produksi Beras Provinsi Sulawesi Utara Tahun 2013. Jurnal Sulawesi utara. 18:254

Wicaksana, N. 2001. Penampilan fenotipik dan beberapa parameter genetik 16 genotip kentang 
pada lahan sawah. Zuriat 12(1):15-20.

Willis, M. 2001. Hama dan penyakit utama tanaman padi di lahan pasang surut. Monograf. Badan litbang pertanian. Balittra. Banjarbaru.

Xing, Y.Z and Q.F. Zhang. 2010. Genetic and Molecular Bases of Rice Yield. Annu Rev Plant Biol. 61:1-22.

Yohida, S. 1981. Fundamentals of Rice Crop Science. IRRI $269 \mathrm{p}$.

Zarrah, S. 2001. A plikasi Pupuk Kandang Dan NPK
Organic Pada Tanah Ultisol Untuk Tanaman Padi Sawah Dengan System SRI (System Of Rice Intensification). Dalam Jurnal Program Studi Ilmu Lingkungan PPS Univeristas Islam Riau. Riau.

Zen, S., H. Bahar, 2001. Variabilitas Genetik, Karakter Tanaman, Dan Hasil Padi Sawah Dataran Tinggi. Stigma 9(1):25-28

Zulman, M dan Widodo H. 2009. Pengujian empat varietas padi unggul pada sawah gambut bukaan baru di kabupaten padang pariaman. Jurnal akta agrosia. 12(1):56-61. 